\title{
Jesus Christ as a teacher and educator - three testimonies
}

\author{
All you need to say is simply \\ "Yes" or "No";
}

anything beyond this comes from the evil one.

Mt 5, 37

A B S TRAC T: The essence of considerations are three testimonies of world-famous intellectuals: Leszek Kołakowski, Tadeusz Kotarbiński and Bogdan Suchodolski about Jesus Christ. The analysis concerns Christ as personified Truth, personified Way and personified life. The adopted perspective is anchored in the teaching of John Paul II.

KEYW ORDS: Metanoia, meaning of life, teacher, testimony, model.

The inspiration to write this reflection on the occasion of the 80th birthday of Prof. Tadeusz Pilch, my teacher, was the discovery of three testimonies concerning Jesus Christ from eminent Polish intellectuals: Leszek Kołakowski, Tadeusz Kotarbiński and Bogdan Suchodolski.

Leszek Kołakowski left behind a text written in French - Jezus ośmieszony (Jesus ridiculed) - published by the Znak publishing house posthumously in 2014, with a preface from his wife: "The French manuscript entitled Jesus ridicule. Un essai apologetique was among Leszek Kołakowskis papers. The text, 
written in the mid-1980s and unfinished, was never finalized and prepared for publication by the author. Tamara Kołakowska, Oxford, August 2014".

This essay is quite extensive, at over 114 pages. The main message contained at the beginning of this fascinating text, these mind and heart moving considerations, is what the author describes as follows: "I think of Jesus as a component of European civilization, so I think of Him as $\mathrm{He}$ has been perceived over the centuries, according to images and stereotypes that we all know not only from reading the New Testament, but also from countless paintings, sculptures in churches, sermons, church tradition and even carols. So I think about Jesus as he is present in the memory of all of us who have believed and lived in this culture. [...] I think of Jesus as true, and that means: truly, genuinely and inalienably present in our history. This presence includes all His words, all His miracles, all His prayers and all His teachings." (pp. 8-9)

The ponderings of Prof. Leszek Kołakowski, gleaming with variablycolored arguments, contain such a reflection: "We have reasons to believe that we need him more than the first Christians, that in essence, the fact that we have forgotten Jesus and, as a result, his most famous commandment, has put us where we are now - often desperate, always fearful, without signs. Is it not so that - as everyone can see - our desperate greed, the ever-increasing spiral of needs, our expectation that all of us, including the richest, not only have the right to have more and more of everything, but actually have more and more - that all this has led us to the point where the accumulated tension will cause a terrible catastrophe? Some priests say this, it is true, but they are ridiculed; that is: Jesus is ridiculed." (pp. 22-23).

Professor Kołakowski clearly shows the core of Christianity and the calling of Christian pedagogy contained in Jesus' commandment here and on the following pages: "A new commandment I give to you, that you love one another." (Jn 13:34) And he sees the salvation of the Christian European civilization in a spiritual change - metanoia - that is, conversion - "a second birth" (Jn 3:3) and speaking the language of faith - a return to the sources of baptizing waters, an act that Europe had experienced in its time. Did it discover the essence and magnitude of the gift it received? In the catechism of the Catholic Church, developed on the initiative of John Paul II preceded by the "Fidei Depositum" Apostolic Constitution, proclaimed on October 11, 1992, on the thirtieth anniversary of the beginning of the Second Vatican Council, in the fourteenth year of Pope John Paul II's pontificate, we can find how the ancient Church Father, St. Gregory of Nazianzus in the work "Orationes": "Baptism is the most beautiful and wonderful gift of God. We 
call it: a gift, grace, anointment, enlightenment, the robe of indestructibility, the renascent wash, the seal and everything that can be the most precious."

Prof. Tadeusz Kotarbiński in his essay "An individual example of shaping of a free thinking attitude" presents a testimony of his own relation to the Catholic religion in the brochure "Religion and I", next to the statements of Leopold Infeld and Bertrand Russell, a brochure published by the Publishing House "Książka i Wiedza" - Warsaw 1962, ed. II - showing his way from faith to atheism. "How happy we were all who felt under the direct care of the 'Mother of God'. I also belonged to those who were placed under her care - by my mother, $[\ldots]$ a seven-year-old boy taken by his mother to Częstochowa, so that before the miraculous painting he could take part in the First Communion after the first confession... [...] At that time I was probably about twelve years old. It was summer. I was thinking about it in the forest silence and it became clear to me that, but not primarily. More like how unhappy those who don't believe must be.

And soon afterwards, I fell alone into the Gehenna of such misfortune. The web of delusion has unwoven into nothingness. I just stopped believing in apparent untruth. I saw through all the unreasonableness of all the arguments of the catechism. No, no, it's good for the kids... I won't be deceived. I will look straight into the face of authentic reality..." (pp. 6-7, 9-10). But in his further ponderings, the Professor makes the following remark: "But it would be a grave ungratefulness on the part of the writer of these words if he did not recognize that one of the important factors was and still is to be concerned from childhood with the reverence and admiration of the past saints, with which he was confronted as the alleged reality of a religious fairy tale. These figures, especially Jesus, the incarnation of a selfless, active and limitlessly sacrificial goodness and a zealous, uncompromising proclamation of the convictions of how to live, and his mother, an image of gentleness and a good heart..." (p. 11)

How puzzling the mysteries of the human heart are! After reading the biographical note of Tadeusz Kotarbiński perfectly written by Wojciech Gasparski in the fifth volume of the Powszechna Encyklopedia Filozofii, published by the Polskie Towarzystwo Tomasza z Akwinu (Polish Thomas Aquinas Society) - Lublin 2004 - the reader finds a remark from the Editorial Office: "Supplementing the information about the life of T. Kotarbinski, it should be noted that in the last days of his life he consciously and voluntarily received the sacrament of the Anointing of the Sick, together with the papal blessing for the hour of death. The sacrament was given by Fr. J. Bazarnik, chaplain at the Institute of Cardiology in Warsaw in the years 1978-1982, 
certifying this fact in writing. This document was transferred to the Kotarbinski archive being created, while a copy certified by a notary public is kept by the PEF Editorial Office.

During my many years of work at the university in Siedlce, over a quarter of a century, I had the opportunity to meet many people with rich life experience. Mr. Ryszard R. was one of those people. He lived through the war in Vilnius. There, together with others in the shelters, in borderline situations threatening life, he envied the people who prayed vehemently. It was easier for them than for a non-believer like me. After the war, Mr. Ryszard was a pupil of Prof. T. Kotarbiński.

It was in the mid-1980s, maybe a little later, he said to me: "I was at a conference in Czechoslovakia. I'll make you happy. Prof. Bogdan Suchodolski made a speech and devoted much attention to the figure of Christ"

Professor Bogdan Suchodolski's monumental work, published in 1990 and consisting of almost half a thousand pages, entitled "Wychowanie mimo wszystko" ("Upbringing in Spite of Everything"), on page 93 in the fragment entitled "Friendship is a human thing", includes reflections on friendship starting with Christ: "One of the factors of European culture, of its ecclesial institutions and, to some extent, of its national morals, was the 'good news' of the Son of Man, who was at the same time the Son of God and who was to be on this earth not only a role model, but at the same time he was to bring the highest and true goodness to its inhabitants in their mortal and future lives. [...] The people, trained in the school of Greek and Roman philosophy, did not understand how a son of man could at the same time be the Son of God and how, having at his disposal the extraordinary power to raise the dead, he could not or did not want to save himself and how God, who was supposed to be his father, could accept this cruel spectacle, which was carried out on Golgotha by the will of lay rulers and a fierce mob" (p. 93) And in further deductions it concerns the matters of wisdom. Man's wisdom and God's wisdom as a centuries-old dispute. "Only from the point of view of this higher wisdom could it be understood how he raised from the dead, recovered his carnal form..." (p. 94)

Jesus Christ in the Gospel of St. John, in its Prologue is the Logos, that is, the Word, Light and Life. Moving on to the second part of this reflection, let us recall the beginning of the Prologue: "In the beginning was the Word, and the Word was with God, and the Word was God. He was with God in the beginning. Through him all things were made; without him nothing was made that has been made. In him was life, and that life was the light of all mankind. The light shines in the darkness, and the darkness has not overcome it." (Jn 1, 1-5) 
The richness of the name Jesus Christ is shown in three biblical languages: Christ Jesus - Christ (Greek: Christos, Hebrew: Massiah, Latin: Christus) - Messiah, Anointed, Jesus (Greek: Jesous, Latin: Jesus) - Yahweh the Saviour (Hebrew: Jehoshua - Jeshua) - Yahweh saves.

The Son of God, the second Person of the Holy Trinity, founder of Christianity. Since his birth in Bethlehem, a new era in the history of mankind has been established. The sources of knowledge of Jesus Christ are the texts of the New Testament - 4 Gospels, Acts of the Apostles, Epistles and the Revelation - as well as the Old Testament in a Christian sense as the announcement of Jesus Christ, and the persons and events of the Old Testament are read in a typical way, so that Adam, Noah, Abraham, Moses and other figures of the Old Testament are types of Christ (the announcement of Christ). He, as the New Moses, will lead humanity, society, and every human being through the "desert" of this life, which ends with death, to the Promised Land, where there is no death, where there is love, where "every tear will be wiped away". These "sources" of the knowledge of Christ as a historical figure are the faith of the Church, where Christ lives as the living center of the Church, where in the liturgy and community you can meet Christ personally, who has overcome evil - Satan, sin on the cross and death leaving an empty tomb.

And what does Christ say about himself?

In a conversation with a great wise man - Nicodemus, who was interested in how to "attain" a life that would not end. Christ responding to him pointed to himself as the minister of life, saying: "Very truly I tell you, no one can enter the kingdom of God unless they are born of water and the Spirit" [...] "Just as Moses lifted up the snake in the wilderness, so the Son of Man must be lifted up, that everyone who believes may have eternal life in him. For God so loved the world that he gave his one and only Son, that whoever believes in him shall not perish but have eternal life (Jn 3:5.14-16)

In another place, he said: "I am the way and the truth and the life" (Jn 14:6). The way, as we know from life's experiences, protects us from error, the truth makes us free, the fullness of life manifests itself through love and joy. The relation with the personified Way, the relation with the personified Truth, the relation with the personified life of every person is a serious matter for pedagogy. In this meeting, millions of people find meaning in life.

During the first "pilgrimage to his native land", Pope John Paul II in the Victory Square, in a multicolored meditation and prophetic message, leaned over this gift, which is Jesus Christ: "The Church brought Christ to Poland - that is to say, the key to understanding the great and fundamental reality 
of man. For man cannot be fully understood without Christ. Or rather, you cannot fully understand yourself without Christ. He cannot understand who he is, what his proper dignity is, or what his calling and ultimate destiny is. And you cannot understand everything without Christ. And that is why Christ cannot be excluded from the history of man in any place on earth. The history of Poland cannot be understood without Christ - especially as the history of people who have passed and pass through this land."

Many of these reflections of John Paul II are a serious "boost" for the thought of school catechesis, building social and national life, but on the basis of respect and affirmation of the human person. When we think of someone as a teacher, we necessarily think of how Christ refers to the children, as he treated childhood beautifully: "Let the little children come to me, and do not hinder them, for the kingdom of God belongs to such as these. Truly I tell you, anyone who will not receive the kingdom of God like a little child will never enter it". (Luke 18, 16-17)

The Gospel message states that he "called the children to him" and, in the words quoted above, indicated them as a sign of new humanity. To become like a child is to make life meaningful. A child has a future ahead of it. In fact - as we can see - the pedagogy of Christ is a demonstration of the way of growing up to the phenomenon of childhood. Immediately after the meeting with the children we can find in the Gospel of St. Luke a description of the encounter with the rich young man, whose great riches hinder him from entering this path, their captivating charm and the inability to leave them behind means that the encounter with Christ ends with a refusal to follow him and sorrow. The didactics of the teaching of Jesus Christ always has the features of a creative and prophetic event, i.e. foreshadowing.

Words and deeds constitute the content of this teaching. He gave his life for the truth of this teaching. He was crucified in Jerusalem. A few centuries earlier, the outstanding Greek teacher and philosopher, Socrates, had met a similar fate. The court in Athens sentenced him to poisoning. Perhaps this can also be interpreted as the foreshadowing of Christ in the pagan world?

This makes it all the more clear in the light of the statements of Socrates' pupil - Plato, who passed on the legacy of thought of his teacher. Plato writes a prophecy about a righteous, a truly righteous man in his treatise "The Republic": "The righteous shall be scourged, tortured and blinded, and eventually, having experienced all torment, shall be nailed to the cross" (Ratzinger 1983, p. 54).

The imposing analogy of Christ-Socrates was repeatedly discussed in various historical periods. The synthesis of these reflections, polemics and 
comparisons was made by the French Dominican T. Deman in his work "Socrate et Jesus" published in Paris in 1944, which was published in Poland in 1953.

The universalistic ethic of the love of Jesus Christ is unique in the history of mankind. None of the known ethical systems includes the commandment to love thy enemies. Although Socrates far exceeded his contemporaries' views by recognizing - in "Crito" - as wickedness the payment for a crime with another crime and evil for evil, but bestowing love on the enemy, the persecutor - this was still unacceptable for Socrates' ethics.

Published before World War II, "Encyklopedia wychowania" (the "Encyclopedia of Education") contains excerpts concerning religious pedagogy prepared by Fr. Dr. Zygmunt Bielawski, professor at the Jan Kazimierz University in Lviv, who, recalling the concept of the English art historian John Ruskin (1819-1900) of seven lamps of medieval architecture - "the spirit of sacrifice, truth, obedience, ideal, pietism of faith, the spirit of love and strength of character." - and transferring to the ground of the anthropology of education, the interior of man, his soul, states that "these candlesticks of the soul light up from the earthly fire of Christ. Only the singular spiritual power can cope with all the brutality of the struggle for existence, which has a deadly effect on the soul; only it has the power to transform the social mechanism into a true state culture". On the other hand, the didactics of Jesus Christ is discussed directly in writing by Fr. Dr. Mieczysław Węglewicz, the general overseer of religion teaching of the Warsaw Archdiocese. The author, painting the scenery of Christ's meetings with listeners - the amphitheater of the Sea of Galilee, its beauty - the altar of nature - tries to define the depth of Christ's contact as the Teacher with people and every human being. Well, Christ, teaching through parables, evoking aphorisms and wisdom, moves listeners both in the intellectual and experiential sphere, everyone can find themselves in these words and parables, discover the truth about themselves and their lives, see the way of love, and thus hear - experience - make an existential decision. It is also stated by Fr. M. Wegglewicz that in the form of the teaching of Christ is "accessible and clear and beautiful, cordial and deep, practical and strong".

Jesus Christ took up public activity at the age of thirty, was a travelling teacher, Christ's mission was prepared by St. John the Baptist and after Baptism in the Jordan, a stay in the desert, he began teaching accompanied by signs and miracles. He had his closest collaborators - the 12 disciples he appointed and called apostles, the second circle of collaborators - these were 70 disciples who went to the surrounding localities and prepared meetings with Jesus 
Christ, there were also friendly families, among the persons supporting Christ and the apostles there were also women.

At the heart of Christ's teaching is the Sermon on Mount - the Eight Beatitudes, the freshness and novelty of which is timeless. And as evidenced by the fascination with the Sermon on Mount of M.K. Gandhi, which he expressed in his "Autobiography", it has an extra-religious range. The great leader of India admits that the words of the Sermon on the Mount, the whole sermon, "found a special place in his heart", and he especially enjoyed these words: "But I tell you, do not resist an evil person. If anyone slaps you on the right cheek, turn to them the other cheek also. And if anyone wants to sue you and take your shirt, hand over your coat as well." (Gandhi 1974, p. 87).

This testimony of Gandhi leads us to the prophetic statement of John Paul II from the Encyclical "Redemptor hominis": "For he, the Son of God, through his incarnation, "united himself somehow with every man. He worked with human hands, he thought with a human mind, he acted with human will, he loved with a human heart, he was born of the Virgin Mary, he became one of us, similar in everything to us except sin. Redemptor hominis, the book "Christ in my life" published in 1982 in the United States as an aftermath of the answer to the question of "Who is Christ to me?" posed by various magazines in the world. It is a living document of the presence of Christ in the lives of those who bear witness to humanity and is a kind of empirical proof of the "union of Christ with every human being".

At the end of this incompetent attempt to touch upon the mystery of Christ the Teacher, let us quote from this collection the following fragment: a 22-year-old worker from Poland, a milling cutter in the Railway Rolling Stock Repair Works, and at the same time a student of the Mechanical Technical Night School, the illegitimate child of a worker: "Who is Jesus Christ to me? I don't know if you can write it that way, but I feel like he was one of our people. He was an ordinary carpenter, he had no education, the apostles his friends - were fishermen, workers, his female colleagues were simple girls, Magdalena, who loved him, had even sold her body before that. He has not written a single book, and now his teachings are paid heed to by the whole world, and it's been so for so many centuries. I sometimes wonder how he did it, that he was a nobody, and then he became someone so great. He was God, he couldn't have been an ordinary man. I sometimes talk to Maria (my stepsister) about how hard it is for us to work and learn (we send some money home because there are still some children there), even though other people find it even worse and harder. 
It was very hard for Jesus, and yet he lived so correctly, without the slightest sin. For me, he is a model of how to live, how to be persistent, wise, brave and of many other qualities. I'd like to get as close as possible to this model. When I sometimes think of him, I feel a little lighter, happier, it's easier for me not to break down, not to give up my studies. Recently, one girl whom I liked said to me while leaving that I 'came from illth', it hurt me a lot, probably because it's true and because I desperately don't want to be like this. Jesus also 'came from illth', they spat in his face, mistreated him and said that nothing good had ever come from Nazareth". (Jana Paweł II, p. 27).

\section{References}

Balthasar H.U. von, 1991, W petni wiary, Kraków. Bartnik C.S., 1987, Chrystus jako sens historii, Wrocław.

Bejze B. (ed.), 1994, Jak dzisiejszemu człowiekowi mówić o Bogu, Warszawa.

Bezimienni mówiq o modlitwie, 1982, Kraków.

Brandstaetter R., 1987, Jezus $z$ Nazaretu, t.1-4, Warszawa.

Blachnicki F., 1992, Tajemnica żywego Kościoła "Światło Życie”, Lublin.

Brosse J., 2000, Mistrzowie duchowi, Katowice.

Bukowski K., 1984, Biblia a literatura polska. Antologia, Warszawa.

Chadom A., 1984, Życie Jezusa według czterech ewangelistów: Mateusza, Marka, Łukasza i Jana. Teksty ewangeliczne, zestawił, opatrzył wstępem i objaśnieniami A. Chadom, Kalwaria Zebrzydowska.

Chrystus w moim życiu, 1982, Stockbridge, Moss.

Deman O.P., Th., 1953, Chrystus Pan i Sokrates, Warszawa.

Dziekoński S., 2000, Wychowanie w nauczaniu Kościoła. Od XIX w. do Soboru Watykańskiego II, Warszawa.

Encyklopedia katolicka, 1997, Vol. 7: hasło: Jezus Chrystus, Lublin.

Gandhi M.K., 1974, Autobiografia. Dzieje moich poszukiwań prawdy, Warszawa.

Gogacz M., 1993, Podstawy wychowania, Niepokalanów.

Hansemann G., 1988, Wychowanie religijne, Warszawa.

Jan Paweł II, 1986, Encyklika Redemptor hominis, Wrocław.

Kołakowska T., 2014, [Oświadczenie], [in:] L. Kołakowski, Jezus Ośmieszony. Esej Apologetyczny i Sceptyczny, Kraków.

Krawczyk R., 1997, Sztuka życia według Biblii, Warszawa.

Kulisz J. SJ, 1995, Wprowadzenie do teologii fundamentalnej, Kraków.

Kulisz J. SJ, Mostowska-Baliszewska A., 1998, Spór o Jezusa Chrystusa w ciagu dziejów, Warszawa.

Kunowski S., 1993, Podstawy wspótczesnej pedagogiki, Warszawa.

Lubac H. de, 1986, O naturze i łasce, Kraków.

Lubac H. de, 1997, Medytacje o kościele, Kraków.

Łępicki S., Gottlieb W., Suchodolski B., Włodarski J. (eds.), 1937, Encyklopedia wychowania, Vol. 1-3, Warszawa.

Majewski A., 1988, Zagadnienia metodologiczne katechetyki, Kraków.

Maloney G.A., 1986, Chrystus kosmiczny, Warszawa. 
Mauriac F., 1937, Życie Jezusa, Warszawa.

Merton T., 1983, Nikt nie jest samotna wyspą, Kraków.

Messori V., 1994, Opinie o Jezusie "A wy za kogo mnie uważacie", Kraków.

Murawski R. (ed.), 1989, Teoretyczne założenia katechezy młodzieżowej, Warszawa.

Ozorowski E., 1984, Kościót. Zarys eklezjologii katolickiej, Wrocław.

Ratzinger J., 1975, Wiara i przyszłość, Warszawa.

Ratzinger J., 1983, Stużyć prawdzie, Poznań.

Ratzinger J., 1994, Wprowadzenie w chrześcijaństwo, Kraków.

Rops D., 1987, Dzieje Chrystusa, Warszawa.

Stownik teologiczny, 1985, Vol. 1 i 2, Katowice.

Świerzawski W., 1984, Pro cuius amore. Myślenie, modlitwa, czyn, Wrocław.

Wychowanie chrześcijańskie, 1982, "Communio. Międzynarodowy Przegląd Teologiczny", no. 5(11). 